脳特よび指循環と振動周波数との関連

\author{
伊藤 史子*
}

\title{
EFFECTS OF LOCAL VIBRATION EXPOSURE ON THE CEREBRAL BLOOD FLOW
}

On the Relation of Brain and Finger Blood Flow to Vibration Frequencies

\author{
Fumiko ITO†
}

The healthy young men aged from 18 to 26 years were examined whether some vibrational stimuli may affect the vasoreaction in the brain and in a finger.

The vasoreaction was observed on each subject after the exposure to vibration of frequencies $32,64,140$ and $250 \mathrm{~Hz}$ with accerelation level at $98 \mathrm{~m} / \mathrm{sec}^{2}$ and compression force at the vibrating grip of $5 \mathrm{~kg}$, while in the control state the vibration was exactly the same except the vibrational stimuli.

Vasodilation and vasoconstriction were observed when low frequency and high frequency vibrational stimuli were given respectively. Vasoreactive pattern of the brain was almost the same as that of the finger.

\section{I. 緒 骨}

振動病はわが国でも最も深刻な問題となっている職業 病の一つである.この疾病の臨床像は, レイノー現象に 代表されるような末梢循環系の異常や知覚障害を主徵と する末梢神経系の異常, さらに自律神経失調や無力症あ るいは前庭症状などを示す中枢神経系の機能的異常が複 雑に絡み合い，今日では「振動病」として系統的全身的 疾患と見なされている ${ }^{1 \sim 3)}$ 。

とくに，これらの多様な症状のらちでも末梢循環系の 異常は本疾患の基本的な症状の一つと解されている.

末梢循環系の異常は, はじめ工具の振動を直接受ける 上肢に最も強く現われるが，進行した段階には足にもレ イノ一現象などの症状が見られることから，血管障害は 全身化すると考兄られている.このような時期には脳や

* 北海道大学医学部公鼻衛生学教室

（現在）金沢大学医学部公衆衛生学教室

昭和 52 年 7 月 13 日受付

† Department of Public Health, Hokkaido University School of Medicine

Present address: Department of Public Health, Kanazawa University School of Medicine

Received for publication, July 13, 1977
心臓にも血管の発作性攣縮によると考只られる症状を起 こすものがあり 4 , 近時, 振動が諸葴器の循環動態に与 える影響が注目されている.

しかし, これまで, 振動暴露でこれらの重要臓器の血 液循環はどのような影響を受けるかを実験的に調べた研 究はない，この問題を明らかにすることは，振動病の病 因を解明するために示唆を与光，なた，労衝衛生学的に も重要である.

そこで, 本研究ではヒトの手に加速度ぶ一定で種々の 周波数条件の振動を暴露し, 脳の血液循環の变化をイン ピーダンス脈波計を用いて観察した。 また同時に，指の 血流を同し方法で測定し，振動刺激に対する体末梢血管 （指血管）と脳血管の反応について比較検討した.

\section{II. 実 験 方 法}

\section{1. 被験者および実験条件}

被験者は実験に習熟した 18 26 歳（平均 21 歳）の健 康な男子学生 10 名である.

実験は被験者の頭部を支持安定した椅座位で行なっ た (Fig. 1).腕は躯幹からわずかに離してほぼ垂直に下 方に伸ばし, 手は振動子のグリップを靕く握らせ, 真上 から $5 \mathrm{~kg}$ の力を加光押した状態を保たせて振動を暴露 


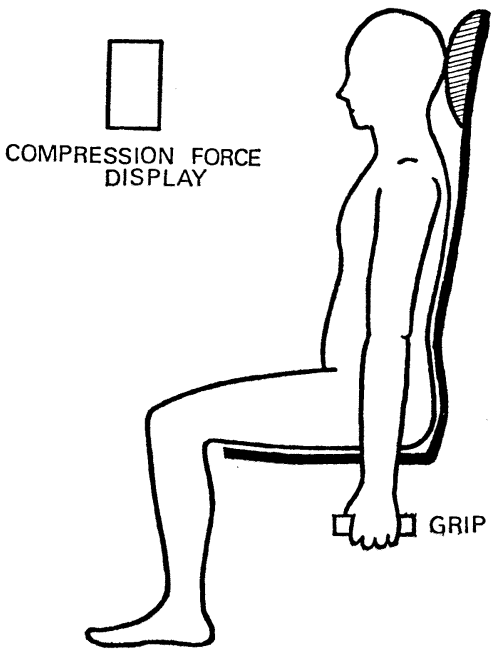

Fig. 1. Posture for vibration exposure.

した.

振動子のグリップはフルミ合金製の丸棒で作り，これ を明石製作所製の動電式 ASE-42 TS 型加振機の振動板 上に固定した．振動子のグリップには，振動レベル測定 のための加速度型ピックアップを取り付け, 実験中, 振 動加速度レベルと加速度波形を監視できるようにした。 また，グリップにはストレンゲージを貼りつけ，グリッ プへの押力を被験者の目の前に置いた力指示計に示し, 常に $5 \mathrm{~kg}$ の力を維持するようにさせた.

暴露した振動は, 周波数 $32 \mathrm{~Hz}$ (低周波), $64 \mathrm{~Hz}$ (中 周波)，140 Hz お。ざ $250 \mathrm{~Hz}$ (高周波) の四種類のほ ぼ正確な正弦波で, 加速度は垂直方向で $98 \mathrm{~m} / \mathrm{sec}^{2}$ (ピ 一ク值) である．暴露時間は各条件とも連続 20 分であ る.

\section{2. 対照実験}

振動暴露時には振動に付随する騒音にも暴露され, グ リップへの押力維持, 姿勢を一定時間保持するための緊 張など諸要因によって血管反応は影響を受けると思われ るので，これらの影響を見る目的で対照実験を行なっ た.この場合, 被験者には振動暴露実験と同一人を用 い，同一姿勢同一肢位で加振装置から遊離した同型同質 のグリップを握らせ, かつ $5 \mathrm{~kg}$ の力で押させ, 力指示 計で押力を監視させ，同時に加振装置は振動暴露時と同 じ条件で作働させて括き，振動暴露時と同様の騒音を暴 露した.

なお，加振装置が作働中に発生する騒音の騒音レベル は $32 \mathrm{~Hz}$ の振動条件のとき, $60 \mathrm{~dB}(\mathrm{~A})[75 \mathrm{~dB}(\mathrm{C})]$, $64 \mathrm{~Hz}$ のとき $67 \mathrm{~dB}(\mathrm{~A})[83 \mathrm{~dB}(\mathrm{C})], 140 \mathrm{~Hz}$ のとき
$79 \mathrm{~dB}(\mathrm{~A})[83 \mathrm{~dB}(\mathrm{C})]$ および $250 \mathrm{~Hz}$ のとき $80 \mathrm{~dB}(\mathrm{~A})$ $[88 \mathrm{~dB}(\mathrm{C})]$ で，無振動状態のバックグラウンドの騒音

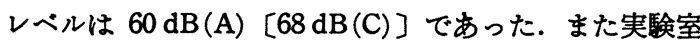
の気温は $21 \sim 23^{\circ} \mathrm{C}$ に保持し, 実験条件の提示順序は, 暴露実験および対照実験とも個々人ごとに無作為に決 め，同一人には 1 日 2 条件以内とした.

\section{3. 血流の測定}

脳および指の血流測定には，作成した定電流四電極方 式インピーダンス脈波計を用いた5)，脳血流の測定は前 頭部で行ない，電極には平板銀電極を用い, 電流電極 （大きさ $3 \times 4 \mathrm{~cm}$ ) を両側側頭部に置き，これらの間に高 周波定電流を流し，血量の变化に伴うインピーダンスの 变化を前頭部に約 $10 \mathrm{~cm}$ の間隔で左右対称に置いた検 出電極（大きさ $2 \times 3 \mathrm{~cm}$ ) により電位差の变化として把 えた．電極はずれないように上からゴムバンドで圧迫し て固定した.

指血流の測定は, 振動暴露側の左手第而指を用い, 各 測定時点において心蔵の高さの台上に上肢を載せた状態 で行なった．電極には接着テープ付き幅 $6 \mathrm{~mm}$ のアルミ ニウム円周電極（米国 $3 \mathrm{M}$ 社製）を用い，四枚の電極を 指に巻きつけ, 約 $3 \mathrm{~cm}$ の間隔に巻いた内側の二枚の検 出電極間の血流を測定した．電極類にはいずれも食塩糊 を塗布し，皮虐との接触を良くした。

電極からの脈波信号は，交流增幅器（三栄測器製 Biophysiograph 180 System) で増幅し, 時定数 0.3 で ペン書きレコーダーの記録紙上に連続的に記録し，振動 暴露実験および対照実験とも，実験刺激前安静時と20分 間の実験刺激終了後 1 分目および10分目付近において紙 スピード $50 \mathrm{~mm} / \mathrm{sec}$ で脳のインピーダンス脈波を測定 し，ついでただちに指のインピーダンス脈波を測定し た. 両脈波の測定の時間的なズレは数秒以内である。

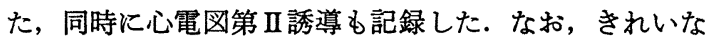
脈波を得るために電極と脈波計をつなぐリード線にはす べて同軸ケーブルを用いた.

\section{4. 脈波の解析}

Nyboer ${ }^{6)}$ はインピーダンス脈波法 で得られた測定值 から次式が電極間に含まれる組織における血管径の変化 に基づく血量の変化を反映するとしている.

$$
\frac{1}{Z_{\mathrm{B}}}=-\frac{\Delta Z}{Z_{\mathrm{O}^{2}}}
$$

ここで, $Z_{\mathrm{B}}:$ 組織の血液抵抗

$Z_{\mathrm{O}}:$ 組織の固有抵抗

$\Delta Z:$ 脈流による可変抵抗の平均値

本研究では, 各測定時点における $1 / Z_{B}$ を求め, これを 


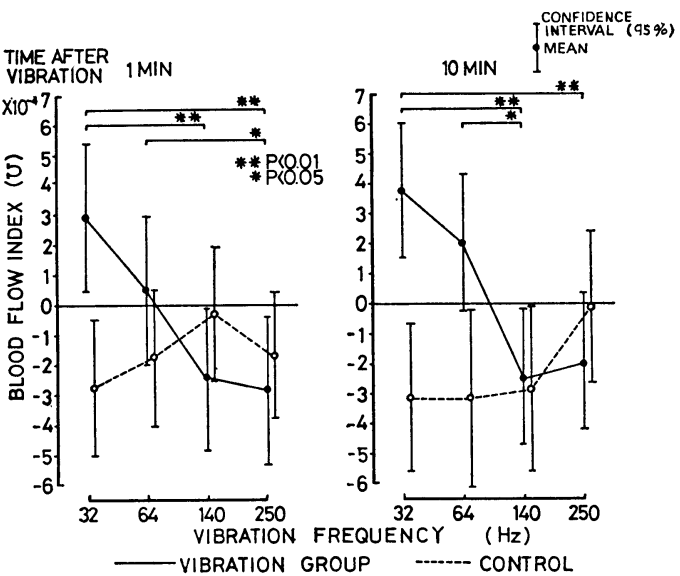

Fig. 2. Effects of vibration exposure on cerebral bloodIflow.

Asterisks show statistically significant changes between vibration exposure groups.

血流指標 (Blood Flow Index) とし, 脈拍補正し, 個々 人ごとに実験刺激前値と 20 分間の実験刺激後の各時点 の差を求め, これを用いて解析を行なった。なお， $Z_{0}$ は脈波計のメーターから読み取り, $\Delta Z$ は測定時付近に 执いてプラニメーターにより求めた $6 \sim 8$ 個の脈波面積 を用いて算出した.

\section{III. 実 験 成 䋖}

各種周波数条件における振動暴露群および対照群の脳 および指の血流の変化は Fig. 2 および Fig. 3 に示す とおりである.なお，以後，振動暴露実験および対照実 験ともに実験条件を加振機の周波数条件をるって表現す ることとする.

振動周波数によって血流指標は影響を受けるかどうか を分散分析法で検討すると, 振動暴露群においては, 脳 では 1 分目および 10 分目とも有意であった（ともに $p$ <0.01).また指に执いてる両時点で有意であった（1 分目 $p<0.025,10$ 分目 $p<0.001)$. しかし, 対照群に おいては，脳・指ともに有意ではなく，したがって，振 動周波数は脳抽よび指の血流に影響を与えていると言え る.

各周波数間の血流指標の差では，脳においては，1 分 目では $250 \mathrm{~Hz}$ と $32 \mathrm{~Hz}$ の間および $140 \mathrm{~Hz}$ と $32 \mathrm{~Hz}$ の間 (とすに $p<0.01), 250 \mathrm{~Hz}$ と $64 \mathrm{~Hz}$ の間 $(p<$ 0.05). 10 分目では $250 \mathrm{~Hz}$ と $32 \mathrm{~Hz}$ の間および 140 $\mathrm{Hz}$ と $32 \mathrm{~Hz}$ の間 (ともに $p<0.01$ ), $140 \mathrm{~Hz}$ と $64 \mathrm{~Hz}$ の間（ $p<0.05 ） て ゙$ 有意であった。すなかち，いずれの

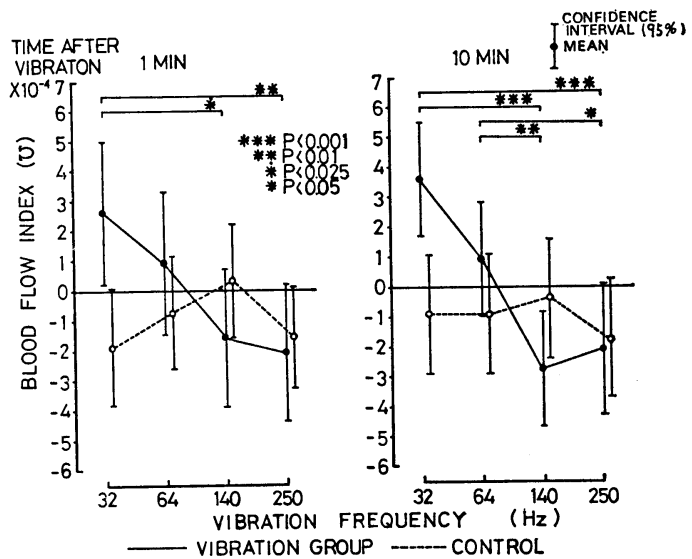

Fig. 3. Effects of vibration exposure on finger blood flow.

Asterisks are the same as in Fig. 2.

時点でも高周波と低周波の間および高周波と中周波の間 に有意差を認めた。 また，指においては，1分目では $250 \mathrm{~Hz}$ と $32 \mathrm{~Hz}$ の間 $(p<0.01), 140 \mathrm{~Hz}$ と $32 \mathrm{~Hz}$ の 間 $(p<0.025), 10$ 分目では $250 \mathrm{~Hz}$ と $32 \mathrm{~Hz}$ の間およ び $140 \mathrm{~Hz}$ と $32 \mathrm{~Hz}$ の間 (ともに $p<0.001$ ), $250 \mathrm{~Hz}$ と $64 \mathrm{~Hz}$ の間 $(p<0.05)$ 抌よび $140 \mathrm{~Hz}$ と $64 \mathrm{~Hz}$ の 間（ $p<0.01 ） て ゙$ 有意であった. すなわち，指において も，高周波と低周波の間および高周波と中周波の間で血 流指標の差は有意であった。

各周波数条件に和ける血流指標の母平均の信頼区間を 推定し, 血流変化の方向性, すなわち, 血流の減少かあ るいは增加かをみると，有意水準 $5 \%$ では，振動暴露群 に扣いては, 脳の 1 分目では $32 \mathrm{~Hz}$ で信頼区間の幅は血 流指標の 0 レベル以上にあり, 有意な血流增加を認め, $140 \mathrm{~Hz}$ および $250 \mathrm{~Hz}$ と扔いては信頼区間は 0 レベル 以下にあり，有意な血流減少を認めた。 また，10分目に おいても同様に $32 \mathrm{~Hz}$ において血流増加は有意であり, $140 \mathrm{~Hz}$ で血流減少は有意であった，さらに，指におい ては, 1 分目では $32 \mathrm{~Hz}$ において有意な血流増加を認 め, また 10 分目でも同様に $32 \mathrm{~Hz}$ での血流増加は有意 であり， $140 \mathrm{~Hz}$ において有意な血流減少を認めた。一 方, 対照群では有意な血流減少が脳に見られた。

振動暴露による脳および指の血流变化の方向にどのよ らな関係があるかをみると，高周波域では $250 \mathrm{~Hz}$ の 10 分目に怙いて相関が認められ $(r=0.82, p<0.01)$, 低周 波域では $32 \mathrm{~Hz}$ の 1 分目に打いて相関が認められた $(r=0.77, p<0.05)$ (Fig. 4).

つぎに，振動刺激のみの血流に対する影響をみるた 
Table 1. Effects of vibration frequencies on the brain and finger blood flow.

\begin{tabular}{|c|c|c|c|c|c|}
\hline \multirow{2}{*}{\multicolumn{2}{|c|}{$\begin{array}{c}\text { Time after vibration } \\
\text { exposure }\end{array}$}} & \multicolumn{2}{|c|}{ Brain } & \multicolumn{2}{|c|}{ Finger } \\
\hline & & $1 \mathrm{~min}$ & $10 \mathrm{~min}$ & $1 \mathrm{~min}$ & $10 \mathrm{~min}$ \\
\hline \multirow{4}{*}{ 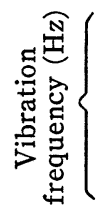 } & 32 & - & $\uparrow \uparrow$ & - & $\uparrow$ \\
\hline & 64 & - & $\uparrow \uparrow \uparrow$ & - & - \\
\hline & 140 & - & - & - & - \\
\hline & 250 & - & $\downarrow$ & - & - \\
\hline
\end{tabular}

Increase of blood flow: $\uparrow(p<0.05), \quad \uparrow \uparrow(p<$ J.025), $\uparrow \uparrow \uparrow(p<0.01)$

Decrease of blood flow: $\downarrow(p<0.05)$

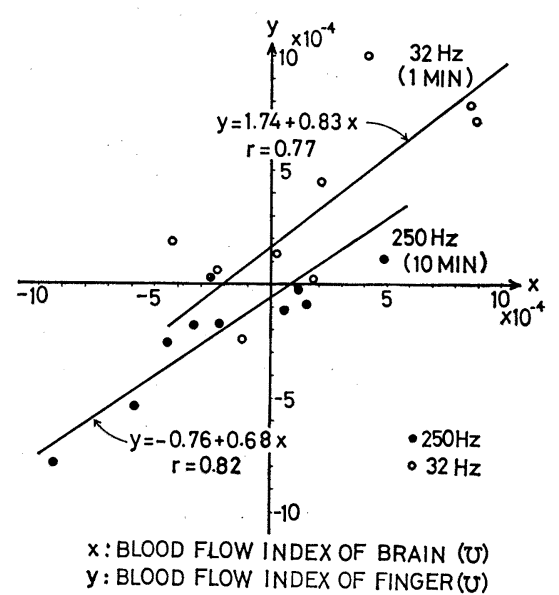

Fig. 4. Relation of blood flow indices between brain and finger.

め, 個々人ごとに振動暴露時と対照実験時の血流指標の 差を求め, 差の平均值の $t$ 検定により血流变化の方向性 をみると (Table 1)，脳化打いては， 10 分目の $32 \mathrm{~Hz}$ $(p<0.025)$ および $64 \mathrm{~Hz}(p<0.01)$ で血流増加は有 意であり， $250 \mathrm{~Hz}$ で有意な血流減少を認めた。指にお いては 10 分目の $32 \mathrm{~Hz}$ で血流增加は有意であった（ $p$ $<0.05)$.

\section{IV. 考察}

振動工具の振動スペクトルと振動病の臨床像を対比し た研究から，末梢血管の異常は暴露した振動の周波数に よって病像が異なることが推察されている.すなわち, 職業的な振動暴露で生じた振動障害では, 患者が暴露さ れていた振動の振動スペクトルが高周波型である場合に は，手に血管揫縮による症状が起こるのが特 徵的であ り，低周波型の振動では，アトニー状態が優位である病 像を呈すると指摘されている4).
また，高周波振動に長期間暴露され，疾病が進行した 段階には血管障害は手だけでなく，全身に拡がることが 指摘されている4). このような段階には発作性の頭痛, めまい, 一過性の意識障害など脳血管の攣縮に基づくと 思われる症状が見られるほか，中权神経系のさまざまな 機能異常による症状も強い。

振動病に打いて中枢神経系症状の発現に脳循環の異常 がどのような役割を演じているか明らかではないが， rheoencephalography による研究では4,7)，患者のらち 体末梢血管障害が強く，その範囲が広いるのほど脳血流 も減少していると述べている.

そこで, 本研究では手への振動暴露で脳血管にも反応 が起こりらるかぞらかその可能性を検討するため, 周波 数の異なる振動を暴露し, 脳の前頭部において血流を観 察した.

その結果, 脳に扣いても実験的な振動刺激で血管反応 が起こり，それは暴露振動の周波数によって異なってい た.この場合, 測定した脳のインピーダンス脈波は前頭 部の血流を反映するものであり, 脳全体の血流変化を反 映するものではないので，この成績をもって脳全体の変 化を推測することはできないが，振動刺激という物理的 環境刺激によっても脳血管は影響を受けることが明らか にされた.

すなわち，低周波振動暴露で血管は拡張し，高周波振 動暴露で収縮した。 また，振動暴露時には付随する騒音 にも暴露され，騒音レベルによってはこれが単独です脳 および指の血管に収縮反応が起こることが知られている ので,99，対照実験を行ない騒音刺激などの影響を見た が，ほぼどの周波数条件でも血流の減少，すなわち血管 の収縮が認められ，本実験においても振動に付随する騒 音が血管反応に及ぼす影響は無視できないことが推察さ れた。

しかし，振動暴露群と対照群の反応の差から，振動刺 
激のみの影響を見ても，低周波で血管は拡張し，高周波 で収縮する（10分目）のを認めた，さらに，同時に観察 した指に拉いても低周波振動刺激で血管は拆張した、ま た高周波領域では血管の収縮傾向がうかがわれた.

以上の上うに，刺激振動の周波数によって血管反応が 異なること，すなわち，周波数依存性があることが明ら かにされた，このような，振動周波数と末梢血管反応と の関連をヒトで調べた研究はこれまでにもいくつかある が，いずれも体末梢血管についてのものである．とれに よると，低周波振動暴露では，木村 ${ }^{10)}$, 那須 ${ }^{11}$ が皮膚温 の低下を認め，血管は収縮すると述べている，一方， 山中 ${ }^{122}$ は指尖光電脈波による研究で $50 \mathrm{~Hz}$ 以下の振動は 血管を払張させると述べている．高周波振動の影響を見 たるのでは, Butkovskaya ${ }^{13)}$, 那須 ${ }^{11}$ は血管の収縮が起 こるとしているが，他の成績は必ずしも一定の法則に従 っていない゙.

このように，周波数と血管反応の関係について必ずし も一定の結論が得られていないのは測定指標の違い, 付 随する騒音などの評価がなされていないことも問題にな るであろう．また，マリンスカヤ4は時間と強さの組合 せによっては，同じ周波数でも血管反応は異なるとして いる.このようなことを考慮すると, 本実験の成績と他 の研究成績との比較は単純には行ない難いであるう.

本研究での振動条件は現実の産業現場でみられる条件 に近いものを採用し,この条件において, 振動を負荷した 手だけでなく，脳において血管反応が見られ，しかも周 波数によって反応の性質が異なることを明らかにしたこ とは労衝衛生学的にも意義があろう。また，脳と指で見 られた周波数依存性のパターンは先に述べた振動病にお ける血管障害の周波数依存性のパターン, すなわち, 高 周波型振動では血管攀縮による病変が起こり，低周波型 振動で血管はアトニー状態を主致とする病変が起こると いら臨床的所見に符合したことは興味深い。

なお，振動刺激に対する血管反応の発現機序について は, 主に次の二つの機序が想定される.すなわち, Gagov ら ${ }^{14)}$ は, ネコの肢に $100 \mathrm{~Hz}$ の振動刺激を与兄た 場合, 肢への神経支配を除いても血管反応が現われるこ とから，振動の直達的作用により血管平滑筋の収縮が起 こると推論した. 一方, Liedtke ら ${ }^{15}$ は, イ邓に低周波 振動刺激を与兄た場合，神経と血管を残して皮庙と関節 を離断して振動云播を遮断した肢でも血管反応が起こる ことから，振動刺激による血管反応は本質的に神経反射 機序によるものと述べている，そこで，脳に起こった血 管反応について考察してみると，まず，振動が手から各 贜器に伝播して血管壁に直達的に影響を及ぼす可能性が
問題となろう.すなわち，振動刺激が人体を伝播すると き, 伝播の程度は周波数によって異なり, 高周波振動は 低周波振動に比して伝播しにくいことが知られてい $ろ^{16)}$. とくに本実験の条件の振動では, 手に負荷する振 動の加速度レベルを等しくしても，低周波と高周波では 手から頭部への伝播には著しい差があり, 高周波領域の 振動の遠隔蔵器への伝播は極めて少ないと考えられる. にもかかわらず, 脳と指といら異なる部位において高周 波振動刺激によって血管の収縮反応が認められたこと は, 脳の血管反応は振動の血管への直達的作用の結果と いらょり，むしろ，上位中权を介した神経反射によると 考えるのが妥当であろう.ささらに，血管反応の周波数依 存性の機序について考察してみると, 振動刺激の刺激頻 度の違いによって知覚神経に発生する求心性インパルス の頻度が異なり, したがって, 求心性刺激を受けて起こ る血管運動反射に和ける血管運動神経のインパルスの頻 度もまた外的刺激の刺激頻度によって何らかの規制が与 えられるためと推察される.このことは, 動物を用いた 研究から, 外界から与えられた機械的振動刺激は Pacini 小体で受容されるのであるが, この受容器は刺激振動の 周波数の広い範囲に和いてその周波数に一致した頻度で 知覚神経に求心性インパルスを送ることが確かめられて いるので(7), 末梢知覚線維あるいは交感神経性血管收縮 線維に一定の刺激頻度で電気刺激を与兄た場合, 昇圧反 応や血管反応の性質と大きさは刺激の強さとともに刺激 頻度に強く規定されることを明らかにした諸研究の成績 は ${ }^{18 \sim 22)}$, 血管反応に周波数依存性が認められたことの神 経学的な根拠を示するのと思われる.

\section{V. 結 論}

振動刺激による脳の血管反応をみる目的で, 健康な男 子学生10名を被験者とし, 左手飞振動子のグリップヘの 押力 $5 \mathrm{~kg}$ の状態で, 加速度 $98 \mathrm{~m} / \mathrm{sec}^{2}$, 周波数 $32 \mathrm{~Hz}$ (低 周波), $64 \mathrm{~Hz}$ (中周波), 140 抢よび $250 \mathrm{~Hz}$ (高周波) の 4 種類の正弦波垂直振動を 20 分間暴露し, また, 対 照実験として上と同一条件で振動因子のみを欠く条件を 用い, 実験刺激終了後 1 分目と10分目に扔いて脳就よび 指の血流をインピーダンス脈波計を用いて測定し, 両者 の血管反応を観察し次の結論を得た。

（1）振動暴露により脳にも血管反応が起こり，それは 振動周波数によって異なっていた。すなわち, 低周波振 動暴露で血管は払張し, 高周波振動暴露で収縮した。

（2）同時に観察した指に执いても低周波振動暴露で血 管は㧪張した. 高周波振動暴露では血管が収縮する場合 があった. 
（3）振動暴露による脳と指の血流変化は, 高周波 (250 $\mathrm{Hz}$ の10分目) および低周波 (32 Hz の 1 分目) で正の 相関が認められた。

（4）対照実験により振動刺激のみをとり除いた諸要因 の血流への影響をみたが，脳においても指においてもど の条件でも血流の差は認められなかった.

（5）振動刺激による血管反応は，脳では低周波および 中周波で挾張を示し, 高周波では収縮する場 合があっ た. また，指においてす同様に低周波で血管拡張が認め られる場合があった。

（6）振動暴露によって起こった血管反応は，本実験の 条件では暴露終了後10分では回復しなかった.

ご教示ご校閲を賜った金沢大学岡田晃教授に深謝の意を表し， 本実験に際し，振動実験施設の使用の機会を怙与えくたさった 労働科学研究所副所長三浦豊彦博士ならびに種々ご協力くたさ いまのた富永洋志夫氏, 肝付邦憲氏, ほか研究所の方々に深謝 いたします.

なお，本論文の要旨は昭和 52 年 4 月，第 50 回日本産業衛生学 会において報告した.

\section{文献}

1) Андлеева-Галанина, Е.Ц., Дрогичина, Э.А. и Артамонова, В.Г.: Вибрационная Волезнь, 95, Медицина, Москва, 1961.

2）高松 誠, 渡部真也 : 振動障害, 久保田重孝編著 : 職業 病とその対策, 511-559, 興生社, 東京, 1968.

3）岡田 晃：いわゆる「白ろう病」, 日本医師会医学講座 (昭和 42 年度), 58-74, 金原出版, 東京, 1968.

4）レタベート,ア・ア,ドロギチナ, エ・ア監筱：産業に おける振動, 131ー257, メディッィーナ出版, モスクワ, 1971, 伊藤史子訳, 渡部真也監修, 労働科学研究所, 1975.

5）伊藤史子 : 局所振動暴露による脳循環系への影留— Impedanceplethysmography の脳循環測定への応用 一, 金沢大学十全医学会雑誌, 87(1) : 掲載予定.

6) Nyboer, J.: Electrical Impedance Plethysmography, 84-288, Charles C. Thomas, Springfield, 1970.

7) Остапенко, О. И., Пятакович, Ф. А.: Состояние церебральной гемодинамику болезных вибрационной болезныю по данных реоэнцефалографии, Гиг. Тр., 16: 52-53, 1972.

8）伊藤史子, 渡部真也：騥音の末梢循環系への影䇾——指
循環および脳循環について一，第50回日本産業衛生学会 講演集, 412-413, 1976.

9) Алексеев, С.В., Мазуркевич, К.С. и Храбова, О.П.: Влияние интенсибного шума на микроциркуляцию в горовнм мозге экспериментальных животых. Гиг. Тр., 7: 24-26, 1972.

10）木村菊二, 阿久津綾子, 三浦豊彦: 振動に扰ける手背皮 庙温の変動, 労働科学, $38: 268-277,1962$.

11）那須吉郎：振動刺激による皮庙温の経時的変化，第47回 日本産業衛生学会講演集, 452-453, 1974.

12）山中 力: 緊張性振動反射の臨床応用，臨床脳波，13： 464-469, 1971.

13) Butkovskaya, Z. M. and Bolderev, Yu. G.: Experimental Investigation of the effect of high frequency vibration on the peripheral blood circulation, Gig. Sanit., 32: 353-358, 1966, [English translation].

14) Gagov, S., Petrov, L. and Natschev, T.: Untersuchung über die lokale Gefaß wirkung mechanischer Vibrationen an der Katzenhinterextremität, Z. Gesamte Exp. Med., 157: 37-46, 1972.

15) Liedtke, A. J. and Schmidt, P. G.: Effect of vibration on total vascular resistance in the forelimb of the dog, J. Appl. Physiol., 26: 95-100, 1969.

16) ラズモフ，イ・カ：人体に対する振動エネルギーの影響, レタベート、ア・ア，ドロギチナ，エ・ア監修：産業にお ける振動, 58一69, メディッィーナ出版, モスクワ, 1971. 伊藤史子訳, 渡部真也監修, 労倬科学研究所, 1975.

17) 勝木保次編: 生理学大系 $\mathbb{N}$, 感覚の生理学, 615-626, 医学書院, 東京, 1967.

18) Gruber, C. M.: The response of the vasomotor mechanism to different rates of stimuli, Am. J. Physiol., 42: 214-227, 1917.

19) Celander, O. and Folkow, B.: A comparison of the sympathetic vasomotor fiber control of the vesseles within the skin and the mustle, Acta Physiol. Scand., 29: 241-250, 1953.

20) Johansson, B.: Circulatory responce to stimulation of somatic afferents.: Chap. III, Blood pressure response to stimulation of somatic afferents, Acta Physiol. Scand., 50 (suppl. 198) : 26-39, 1962.

21) Koizumi, K., Sato, A., Kaufman, A., McC Brooks, C.: Studies of sympathetic nervous discharge modified by central and peripheral exitation, Brain Res., 11 : 212-224, 1968.

22) Barman, S. M., McC Caffrey, T. V., Wurster, R.D.: Cardiovascular and electrophysiological response to sympathetic pathway stimulation, Am. J. Physiol, 230: 1095-1100, 1976.

著者への通信先 : 伊藤史子, $=920$ 金沢市宝町 13-1 金沢大学医学部公衆衛生学教室 Reprint requests to Department of Public Health, Kanazawa University School of Medicine, 13-1, Takaramachi, Kanazawa, 920 Japan (F. Ito) 